\title{
Coral reef fishes which forage in the water column
}

\author{
A review of their morphology, behavior, ecology and evolutionary \\ implications \\ W. P. DAvis ${ }^{1}$ \& R. S. BirdSONG ${ }^{2}$ \\ ${ }_{1}^{1}$ Mediterranean Marine Sorting Center; Khereddine, Tunisia, \\ and \\ ${ }^{2}$ Department of Biology, Old Dominion University; Norfolk, Virginia, USA
}

EXT'RAIT: «Fourrages» des poissons des récifs de coraux dans la colonne d'eau: Morphologie, comportement, écologie et évolution. Dans un biotope à récif de corail, des espèces étroitement liées peuvent servir d'exemple de différenciation sur le plan de l'évolution. La radiation évolutive de poissons représentant plusieurs familles du récif corallien tropical a conduit à plusieurs reprises à la formation de «fourragers dans la colonne d'eau». Ce mode de vie comporte une série de caractères morphologiques et éthologiques définis. On trouve des éxemples similaires dans l'eau douce et dans des habitats non tropicaux. Les traits distinctifs de cette spécialisation, la systématique, les caractéristiques écologiques et celles se rapportant à l'évolution sont décrits et discutés.

\section{INTRODUCTION}

The rapid adoption of in situ studies to investigate lifeways of organisms in the oceans is succeeding in bringing the laboratory to the ocean. Before, the conclusions that observers and scientists were classically forced to accept often represented inaccurate abstractions of things that could not be observed.

During the past 10-20 years the cataloging of the fauna and flora of the coral reef habitats has been carried out at an escalated rate, coupled with the many and vast improvements in tools, allowing increased periods of continual observation under sea. Today we tend to think the great effort expended in Florida's Tortugas Islands by LONGLEY \& HILDEBRAND (1941) as quaint with "hard hat" diving apparatus, manganese flash bombs and ponderous underwater camera apparatus. Yet a fundamental piece of work was produced, quoted in the majority of subsequent treatises, whether these works deal with additions to South Florida faunal lists, or descriptions of fish behavior, color, or feeding habits. There is a continuing effort to make meaningful assessments of the fauna, and to evolve realistic models of the tropical marine environments with the complex coral communities and reef inhabiting organisms.

Studies of coral reef fish feeding habits (Longlex \& Huddebrand 1941, HiatT \& Strasburg 1960, Randall 1963, 1965, 1967, 1968b, Hobson 1968, 1973, and 
others) have all contributed greatly to an understanding of ecological relationships of tropical marine fishes, by their detailed assessments of feeding habits and predatorprey relationships. Other studies focusing on specific species, or species groups are supplying the information and data bits for more detailed understanding; e. g. gray snappers (STARCK \& SCHROEDER 1971), wrasses (FEDDERN 1963, 1965), garibaldi fish of California (Clarke 1970), anemone fish (ALLEN 1972). Through these efforts, the undersea biologists are closing the knowledge gap with counterpart studies in fresh water and terrestrial habitats. Investigations of these terrestrial habitats have had over a century's head start in producing sufficient data to allow synthesis and further development of realistic and functional community models. Recent models of marinereef community relationships exemplified in SMITH \& TYLER's (1972) studies of "space sharing" are soon to become classical examples in evolutionary biology, along with LACK's (1971) brilliant studies on ecological isolation in birds, illustrating the dynamics of animal relationships in communities. Through application of some of the concepts, summarized by LACK (1971), to coral reef communities, we will soon (if it is not already underway) witness production of a devoted school of sea-invading "fish watchers", exploring the great biological frontier of ocean habitats with the remaining myriad problems in behavioral, color, habit, habitat interrelationships among members of faunal communities, which have just recently been cataloged (EIBL-EIBESFELDT 1962, Fishelson 1964, Talbot 1965, Starck 1966, 1968, Böhlke \& Chaplin 1968).

Some of the earlier concepts of ecological structure of the reef communities are now changing, and will continue to be modified as new data is collected. In earlier observations, insufficient data and comparisons sometimes led us to adopt definitions which through continued literature quotation have become conceptions of misplaced concreteness; not always relevant, nor entirely accurate.

This paper is a synthesis of the two authors' own observations, together with observations from published works dealing with a common and important resource exploitation in the aquatic environment: foraging in the water column. It brings together the data from food studies, morphology and community structure on coral reefs and demonstrates a way of making a living - a "mode of existence", "resource exploitation" or whatever one wishes to call it; this situation should be recognized by the undersea investigator, and is clearly to be seen by even the novice diver. The relevance of this means of existence in the community is emphasized by the number of fish families dwelling about coral reefs, or in analogous environments, from which have evolved species members exhibiting the set of characteristics and specializations of behavior and morphology typifying water-column foragers. This mode of living has been generally accepted, perhaps too glibly, so that details of its significance have not previously been pursued in sufficient depth.

The examples which are used here to illustrate these specializations for water column foraging are drawn mainly from the so-called coral reef community, although using the terminology "association of fishes f $\mathrm{requent}$ in $\mathrm{g}$ coral reefs" might be more realistic. There exist very obvious parallel examples elsewhere, both in the oceans in latitudes where reef-building corals do not thrive, and in certain freshwater environments. This "parallel evolution" itself, further emphasizes the relevance of the concept. Additionally, many of the morphological features to be discussed are also 
found in fishes which are more pelagic, and by their nature are not habitually associated with coral reefs, providing still another argument of validity of the concept.

The choice of fish examples whose greatest number of existing related species frequent the coral reef habitat is purposeful: use of this type of example allows definitions of the life-ways which are not stretched too thinly. Species from the same habitat can be compared, allowing a clear conception of how resource exploitation upon the coral reef takes advantage of nearly every conceivable combination of factors and possibilities. Where else in aquatic environments can one find so many fish species within a definable community? Furthermore, the features and behavior to be described are not deductions simply made in the laboratory of the morphologist, but are synthesized from hundreds of in situ observation hours on reef habitats taken and compared with the summaries of the morphology, with stomach-content analyses, and the results of studies of community structure.

\section{WHAT CORAL REEF FISH FORAGE IN THE WATER COLUMN?}

Various authors in their respective descriptions of marine fish communities have referred to the "plankton feeders", the "particulate plankton pickers", the "fusiliers", carnivores in mid-water, the "hoverers", or "pelagic relative" of other substrateforaging species, and in numerous ways avoided clearly designating fishes which forage and feed principally in the water column. In one case an author states he intentionally omitted the weight of a shoal of these fish from his calculations of biomass of reef fishes because he felt they were too "neritic". Actually, he simply had no idea of the home range of the shoal of this species.

We will compare examples of water-column foragers, with benthic foraging fishes in the same coral reef community. SMITH \& TYLER (1972) demonstrate a case of "resource sharing" where diurnal and nocturnal water-column foragers replace one another in resting shelters over the 24 hour cycle, much as Hobson $(1965,1968,1973)$, Starck \& Davis (1966), Collette \& Talbot (1972) and others have described the diel rhythms of reef fishes engaged in benthic foraging.

A general impression of water-column foragers is illustrated by the artist's renditions of the ecology of the Hawaiian shelf from the research submarine "Asherah" (Brock \& Chamberlain 1968). The fish "swarms" or aggregations of fishes hovering over submarine terraces illustrate fish in the habitat of water-column foragers. The remaining criteria are: are these fishes actually in search of prey; are these fishes "coral reef" forms?

If we seek counterparts in terrestrial ecology (MACARTHUR \& LEvins 1964, Root 1967), among birds we would consider the "flycatchers". Whereas swallows and martins might be "too neritic", flycatchers have a better understood territory, associated with particular habitats (LACK 1971).

\section{RESOURCES OF THE WATER COLUMN}

Having briefly introduced the concept of the habit and the habitat, what is the resource under exploitation? The currents and water movements over a reef, shelf, or 
terrace purvey many food items, phytoplankton, planktonic larvae, and simply supply the "lift" or movement for a community of smaller reef-associated organisms to use for locomotion or "sailing" over the fore reef during foraging or other movements into the water column. As is typical with most habitats, the interfaces such as the case at ledges or coral reefs are normally the richest in diversity and density of species. These interfaces represent the "cross roads" between foraging and refuge areas. The coral colonies themselves, as well as the associated organisms respond to this resource enrichment. The changes in species composition of the community from the reef front through the back reef is another reflection of changing resources and, therefore, subsequent resource utilization.

In the example under discussion, "water column foraging" may be engaged in by differing species on the open ocean edge of the fore reef, compared with a portion of the water column above the reef platform, or to areas located above the back reef and/or the reef lagoon. Perhaps these gradients of habitat, and changing communities such as this example across an isolated reef, combined with selection pressure and response to ecological isolation is the basic model for evolving water column foraging from other feeding specializations. Certainly evolution of fishes has repeatedly produced species which forage in the water column in such fish families as Gobiidae, Apogonidae, Pomacentridae, Labridae, Pomadasyidae, Serranidae and the other speciose groups. Certain species examples with this foraging habit possess rather less morphological specialization than other specific forms (STRAsBurg 1966). In the example of the pomacentrid Abudefduf saxatilis, which is commonly cited as an example of "particulate plankton pickers", we find it also regularly forages benthically and places other than the water column. Randall's (1967) food data show a fairly even spread between water-column and benthic prey in the stomachs of 35 specimens he examined.

EMERY (1968) has examined examples of copepods and mysid shrimps and other invertebrates which are seen in "swarms" off faces of reef ledges, and although normally they are thought of as planktonic forms, maintain themselves oriented to bottom features and are not part of the "nature adrif" community. These "schools" or swarms of small invertebrates are part of the food resources exploited by the watercolumn foragers. EMERY (1968) further makes an excellent point by stating that the importance of "plankton feeders" other than the coral should be carefully reexamined, their relative role perhaps being previously underestimated. Schooling plankton have the very important potential role in the capture of off-shore nannoplankton and phytoplankton. AlLDREDGE (1972) supports EMERY's projection in her observations of certain copepods' utilization of abandoned larvacean houses for food resources. The nannoplankton entrapped in the mucous of the house often is smaller than the filter apparatus of the consuming copepods. This resource subsequently passes through the reef food web via predation including fish foraging in the water column.

In coral reef fish communities we find several species foraging in the water column from a "home base" on the reef within a relatively restricted habitat or home range. A series of examples have been chosen, representing a number of families with wide geographic distribution, but which classically have been considered reef fishes. These water column foragers are compared with benthic-foraging relatives normally found 
on the same reefs in South Florida or the Caribbean, to illustrate the distinguishing features of these differing forms and mode of resource exploitation.

\section{COMPARATIVE MORPHOLOGY OF WATER-COLUMN FORAGERS AND RELATED BENTHIC FORAGERS}

The practical morphologist, whether or not he happens to be an "in situ" fish watcher, will recognize the modifications for foraging in the water column involved in the features: form of jaw, relative size and placement of eye, form of pectoral and caudal fins, body shape, dentition of jaw, pharyngeals, gill rakers and sometimes squamation (Fig. 1).

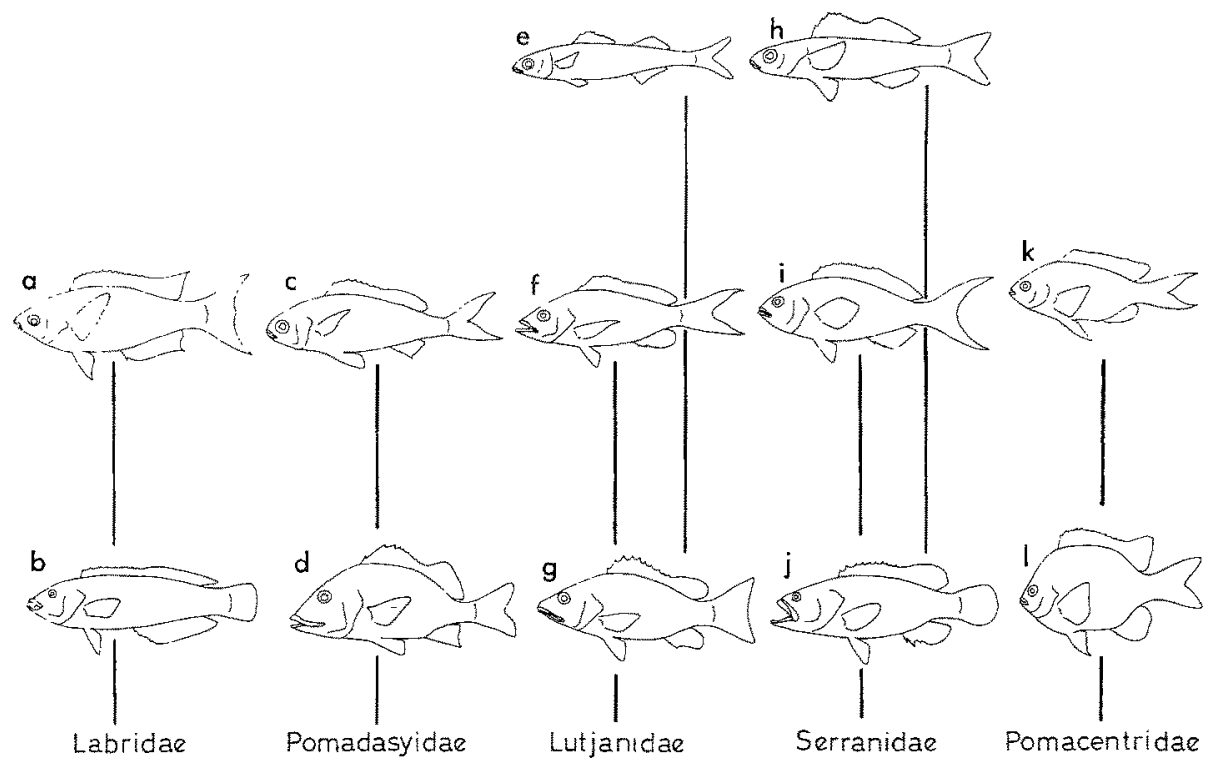

Fig. 1: Comparison of general body shape and fin configuration of benthic foragers with water-column foragers among some perciform families. No phyletic sequence is implied. Generalized piscivorous or benthic foragers: (b) Halichoeres poeyi, $(d)$ Haemislon sciurus, (g) Lutjanus griseus, (j) Epinephelus cruentatus, (l) Abudefduf saxatilis. Water column foragers: (a) Clepticus parrai, (c) Haemulon striatum, (e) Emmelichtbyops atlanticus, (f) Ocyurus chrysurus, (b) Schultzea beta, (i) Parantbias furcifer, $(k)$ Chromis cyanea. Examples not drawn to scale

The number of species used to illustrate the hypothesis is restricted in this section; many more examples exist. Also, in our consideration of water-column foragers, we are not including strict phytoplankton feeders, as exemplified by herrings, where specialization has evolved sieving or straining modifications in the feeding apparatus. Therefore, "plankton picking" becomes a cogent generalized term to describe the behavioral convergence under discussion, at least until one examines actual feeding. Figure 1 illustrates outlines of body forms of a series of water column zooplankton 
foragers, compared with related species foraging elsewhere on South Florida coral reefs. Certain basic external features distinguish the water-column foragers: (1) More "lunate" form of caudal fin. (2) Tendency for a more falciform type pectoral fin. (3) Tendency towards a more terrete body outline, narrowed and more streamlined, including a sharper profile of the nose and head. (4) Finer squamation (not illustrated in Fig. 1). (5) Tendency for relatively large eye size, proportional to the head size.
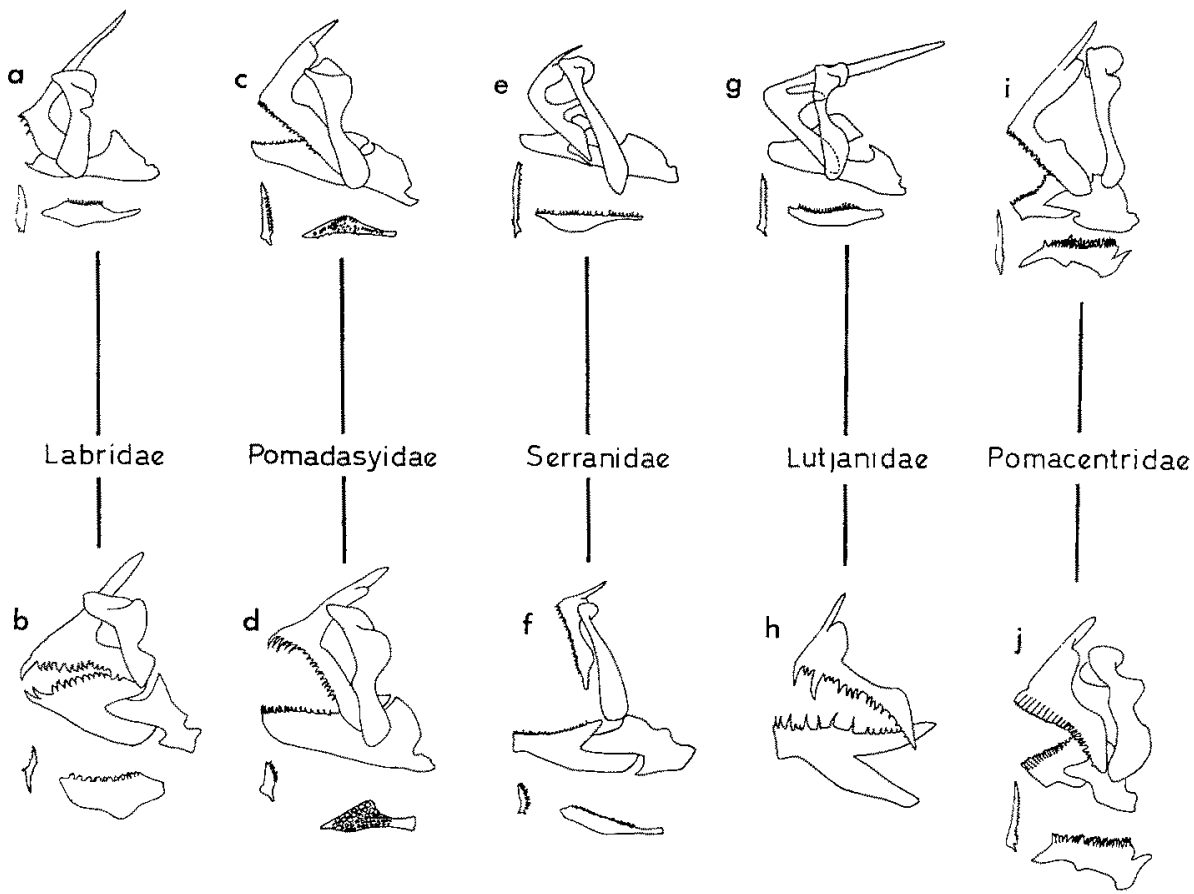

Fig. 2: Comparison of jaws, dentition, gill rakers and lower pharyngeals between benthic foragers $(b, d, f, b$, and $j)$ and water-column foragers $(a, c, e, g$, and $i)$. Examples and their arrangement do not imply phyletic sequence. (b) Halichoeres poeyi represents a benthic invertebrate picker; (d) Haemulon sciurus, a carnivore on invertebrates with crushing pharyngeal apparatus; $(f)$ Epinephelus cruentatus, principally a fish gulper; (b) Lutjanus griseus, a carnivore which seizes invertebrates and fishes; $(i)$ Abudefduf saxatilis, an ubiquitous form which feeds by benthic scraping on algae and invertebrates and also in the water-column on plankton. Water-column forager jaws, gill rakers, and pharyngeal teeth illustrated by (a) Clepticus parrai, (c) Haemulon striatum, (e) Scbultzea beta, (g) Emmelichthyops atlanticus,

(i) Chromis cyanea

In Figure 2 we see that morphology of feeding apparatus also follows recognizable trends: (6) Finer dentition on the jaws. (7) Finer teeth on the pharyngeal plates. (8) Gill rakers are longer and more numerous and finely toothed. (9) Somewhat reduced ossification of jaw and head bones, particularly those head bones where insertion of muscles controlling "grinding" functions are attached. (10) Longer premaxillary processes together with greater protrusibility of the jaw.

Points (6) and (7) are particulary clear in the example in the genus of "grunts" Haemulon: where benthic foragers $H$. plumieri or $H$. parrai have crushing molariform 
pharyngeal teeth, whereas $H$. striatum has very fine needle-like teeth and feeds upon copepods in the water column (Davrs 1967). This general trend also occurs in the lutjanid Ocyurus chrysurus, serranid Paranthias furcifer and carangid Decapturus punctatus. In two of the most highly modified zooplankton picking species, Schultzea
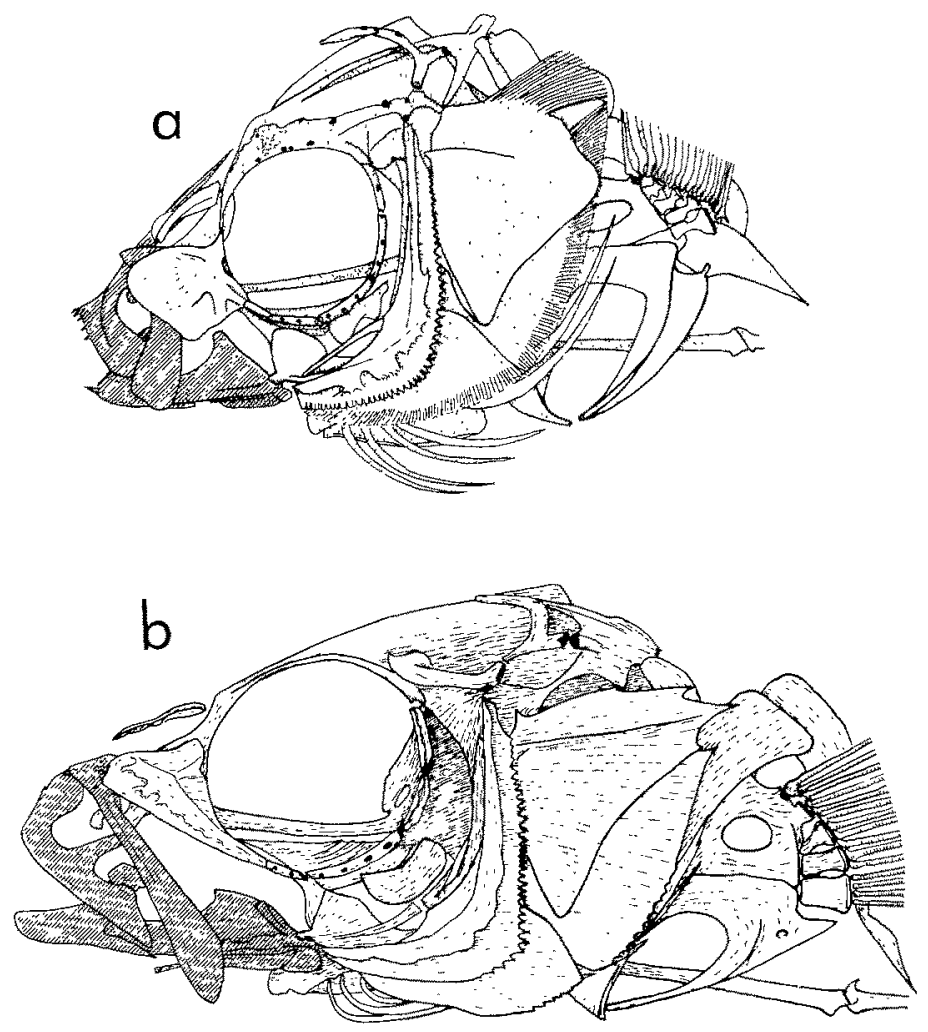

Fig. 3: Articulated skulls showing jaws of two water-column foragers: (d) Clepticus parrai, UMML 20174; (b) Schultzea beta, UMML 18813

beta (a serranid, Robins \& STARCK 1961) and Emmelichthyops atlanticus (closest phylogenetically to lutjanids), teeth are completely absent from the jaw. However, these two examples (and some closely related species) have developed the greatest protrusability of the mouth.

This morphological specialization is reflected in relatively enormous development of the ascending process of the premaxilla (Figs 2 and 3). In the cases of the wrasse Clepticus parrai, and Intermia vittata (a species closely related to Emmelichthyops), the premaxillary process extends back over the skull a considerable distance between the eyes. In two species, Emmelichtbyops and Schultzea, an additional process is found on the premaxilla which apparently serves in giving support to the large resulting gape between the maxilla and the premaxilla; this gape is covered only by integument 
when the jaw is shot forward. When feeding, these fishes "shoot" the jaw forward and downward rapidly; this rapid expansion of the oral cavity creates a suction which draws prey into the cavity (Fig. 4).

Therefore, plankter prey are not truly "picked" or seized by the teeth as in more piscivorous fishes, but instead are slurped or sucked in. Fresh stomach contents reflect this feeding action by yielding entire, little-damaged specimens of prey organisms.
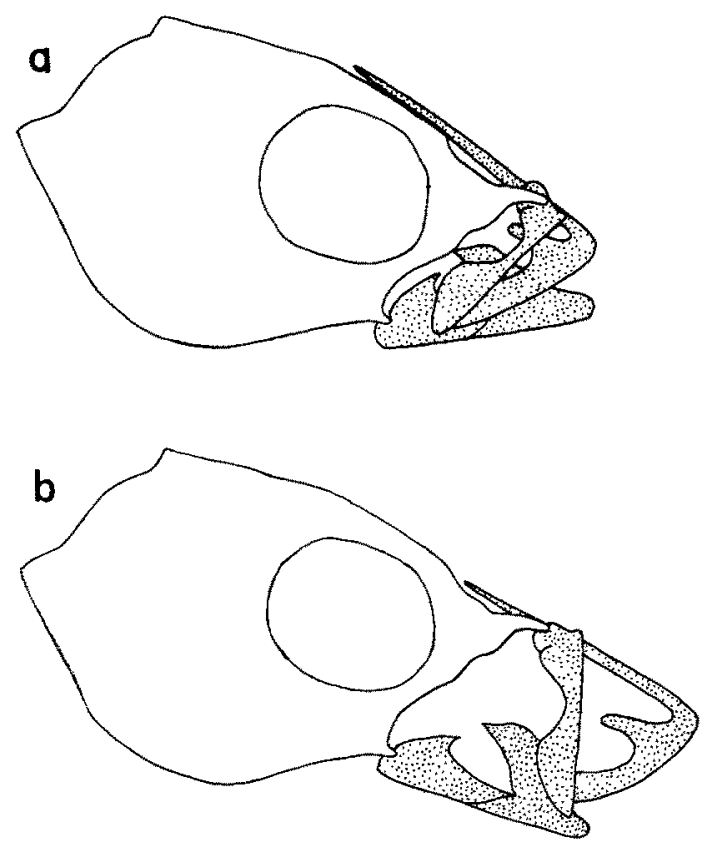

Fig. 4: Emmelicbtbyops atlanticus; jaw mechanism (a) jaws unprotruded, (b) jaws protruded

Reconsidering the "convergence" of body form of the water-column foragers, one feature which is not illustrated here is their relatively smaller body size (except in labrids, pomacentrids and godiids), compared with benthic foraging relatives: typically the plankton feeding species are among the smaller members of their respective $f a-$ milies. The relation of forager to the size of its prey must be further investigated to determine correlations of body size with energy/nutrient-flow relationships. Correlated with this smaller body size is the relative size of the eye which, depending upon how comparisons are made, tends to be proportionally larger among plankton feeders. There is good logic to the argument that this feature is an indirect, rather than a direct correlation; since most head and jaw structures are morphologically reduced among the water-column foragers, and the actual eye size is not significantly different from other related species. As noted, the body tends to be more fusiform, with a strongly forked caudal fin, tending towards the lunate tail of fast pelagic fishes. These adaptations all are for fishes which engage in continuous swimming, without frequent starts and stops. Interestingly, Clepticus, the plankton-picking wrasse, continues to swim 
like a labrid with "pectoral sculling" in normal swimming. However, under stress it becomes a swift swimmer utilizing more body and tail propulsion.

\section{SCHOOLING PATTERNS COMPARED BETWEEN WATER-COLUMN AND BENTHIC FORAGERS}

The behaviorist and fisheries biologist will recognize differences between benthic and water-column foraging in: (11) Nature of schooling. (12) Comparative pigmentation and coloration. (13) Time of foraging. (14) Nature of food.

As noted in the introduction, water-column foragers may be recognized by their swarms, or schools over areas of the reef or similar submarine features. These schools are not highly organized, but a degree of spatial organization is maintained. Very often the schools are composed of mixed groups of two or more species. In cases where the pomadasyid Haemulon striatum and the lutjanid Emmelichtbyops atlanticus are found in the same feeding school (both are diurnal feeders), the pigment patterns and color tend to be very similar making it difficult to distinguish the two species, even after some experience in underwater observations (DAvis 1967). These features are in general agreement with the defensive function of the shoal (MANTEIFEL \& RADAKOV 1961, Hobson 1968, 1973), especially for these smaller fishes which are exposed in open water during their foraging. DAvis (1967) compares schooling among the South Florida pomadasyid species in more detail, but in summary, Haemulon striatum and other foragers used in the examples to this point forage in diurnal schools. At night, schools of these species disperse and individuals are found in resting states among the reef features, or elsewhere on the bottom (STARCK \& DAvis 1966). This demonstrates the role of sight among these particulate plankton feeders. Other modes of exploiting water-column foraging are further discussed shortly.

A notable contrast to this pattern of diurnal water-column foraging in Haemulon striatum is the case of $H$. chrysargyreum, in which diurnal schools break up, and individuals nocturnally forage in the water column. Food analyses by RANDALL (1967) and DAvts (1967) reveal the stomach of this species (analyzed both by percent of occurrence, and of volume) to contain larval forms, polychaetes and other invertebrates which nocturnally enter the water column to forage or reproduce. Similarly, apogonids, pempherids, carapids, holocentrids (Myripristris) (STARCK \& DAvIs 1966, Randall 1967, Hobson 1968, 1973, Collette \& Talbot 1972) all enter the water column and feed nocturnally. It is notable that feeding, either diumally or nocturnally, more often is phylogenetically correlated to the family level, whereas benthic versus water-column foraging specialization occurs at the genus/species level among speciose groups.

The locations of the foraging schools are dependent upon the species. The wrasse Clepticus parrai, the serranid Paranthias furcifer and the pomacentrids Chromus cyanews and C. multilineatus have less typical "schools" in the traditional sense, and are more aptly described as having "vertical foraging aggregations" (for genus Chromis, see review by ColletTE \& TALBOT 1972). These species tend to retreat to sites on the reef when pursued. Haemulon striatum and Emmelichthyops present examples 


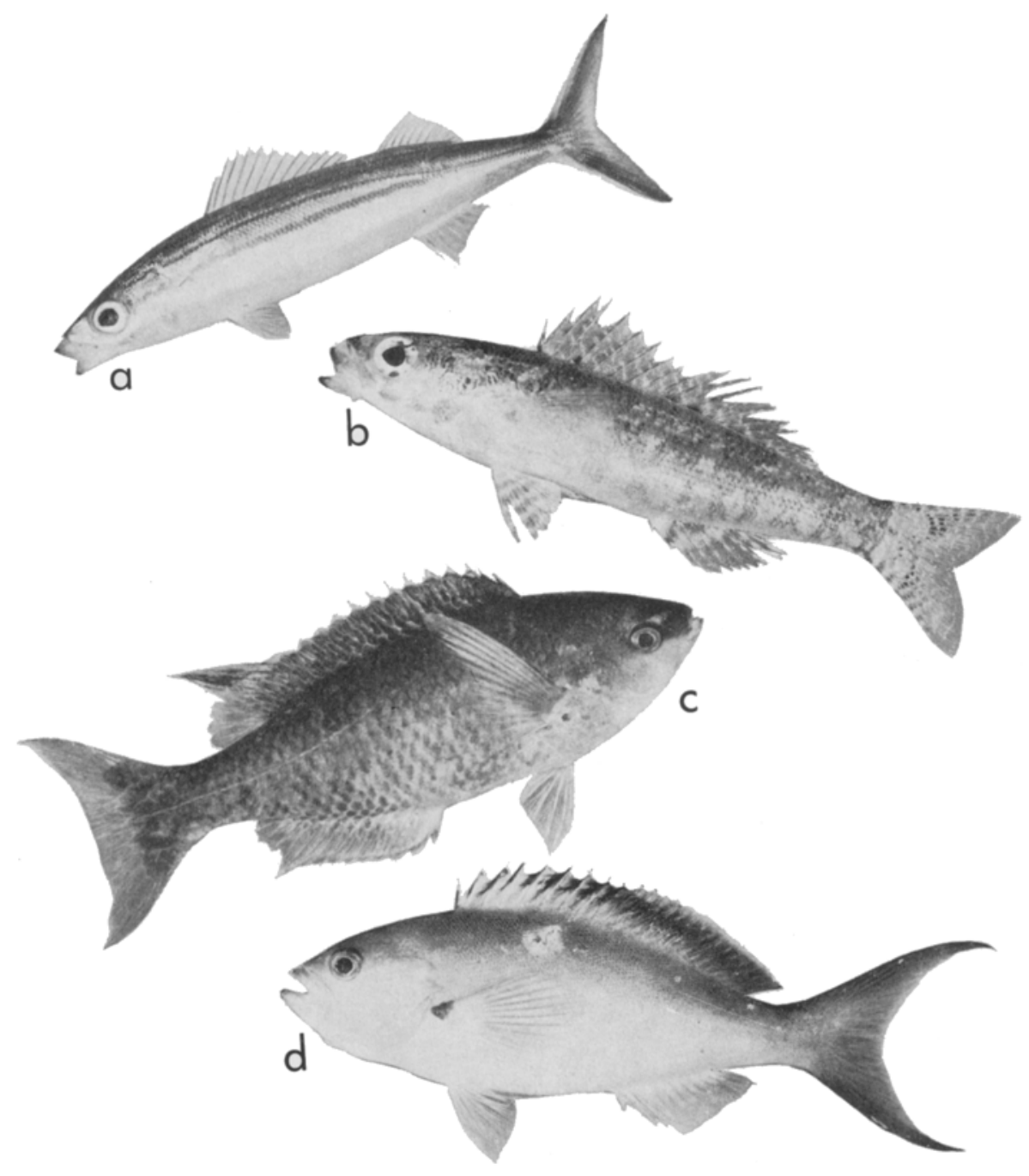

Fig. 5. Examples of pigmentation among coral reef water-column foragers: (a) Emmelichthyops atlantictus with longitudinal stripes; (b) Schultzea beta (fins somewhat frayed) with mottled pigmentation; (c) Clepticus parrai, and (d) Parantbias furcifer both illustrate variation of shading. Color illustrations of these examples are found in RandaLt (1968). Parantbias has a spear wound. (Illustrations from transparencies of fresh specimens made by W. A. STARCK II)

of more classical diurnal schools which do not retreat to specific bottom features when under pursuit. Schultzea aggregations are arbitrarily midway between Clepticus parrai and H. striatum. Schultzea is the best example to introduce a short discussion on "hovering" since this species typically is observed hovering over features on the substratum. 
Hovering among water-column foragers presents some contrasts to examples cited for foraging schools. Typically, hovering fishes prey upon food items in the immediate vicinity of a burrow or grotto. Hovering fishes may form aggregations with colonies of burrows found in some regions of the reef, or adjacent habitats. They represent a recognizable group, with examples in many families. Ioglossus, Ptereleotris (Gobidae) and Trimma tevegae (COHEN \& DAvis 1969) are examples of split-fin gobies engaging in hovering on or near coral reefs; Corypbopterus personatus represents one of the numerous cup-finned gobies; Opistognathus aurifrons (Opistognathidae), Malacanthus plumieri (Branchiostegidae) are among the many examples of hovering fishes.

Among the remaining means, contrasting with school formation or hovering to exploit water-column foraging, is extension into the water column from a burrow as in the garden eels Taeniconger and Gorgasia (Congridae), described by Hoвson (1968), FRICKE $(1970,1972)$ and others, and "climbing" into the water column on some other object as in the case of Cottogobius (DAvis \& CoHEN 1968).

Again we suggest further studies be made regarding the nature of schooling, zooplankton feeding to test relationships between body size, distances travelled, size and quantity of prey and duration of foraging. The space-sharing concept of SMrTE \& TrLLER (1972) clearly indicates that supply of hiding places is a most important limiting factor, perhaps more than food, on Western Atlantic coral reefs. Schooling in a sense, therefore, provides an "evolutionary escape" from ecological limitations of hiding space, at least for fish derived from benthic progenitors.

Pigmentation is a most difficult factor to deal with, whether distinguishing species, or attempting a detailed description in words. Color obviously is an important and flexible adaptive feature to the living animal. It would be very surprising if one could make an all-inclusive statement of how water-column foragers could simply be distinguished by color or pigmentation pattern. It, therefore, should not be surprising to state color and pigment patterns vary with specific examples. Many diurnal watercolumn foragers, in shallow waters, near reef faces, are blue or indigo suggesting some blending with the "blue glow" one perceives from scattering of light in clear tropical waters.

Certain other examples, especially the forms which have well-developed schools, are frequently longitudinally striped which makes a single individual in a school more difficult to distinguish (Fig. 5). Scbultzea beta has a mottled appearance (Fig. 5) which might be considered "atypical" unless one recalls this form aggregates near bottom features, where it retreats during pursuit, and is typically found in deeper water $(20-75 \mathrm{~m})$. Paranthias tends to have reddish to purple hue and its schools extend into open water over reefs $20 \mathrm{~m}$ and deeper (SMITH 1971). Some hovering fishes discussed tend to have light shading (hue) of green or blue, but they also are more frequently over burrows in high albido coralline sand areas, rather than near rocks or coral heads (e.g. Microgobius carri, Isoglossus, Opisthognathus aurifrons and Malacantbus).

Nocturnal foraging forms tend to have red pigmentation, as in apogonids, Myripristis and even Carapus. In Haemulon chrysargyreum diurnal schooling pigmentation correlates with other diurnal schooling grunt species, but nocturnally its pigmentation fades, leaving a blanched fish which feeds over open sand substrates. Another behavioral feature of coloration is discussed later. 


\section{EVOLUTIONARY IMPLICATIONS OF WATER-COLUMN FORAGING}

In studies on relationships of ecology with morphological functions, one takes the basic premise that ecology of an animal is indeed reflected in the morphology. However, this turns out to be only partly true. SUYEHIRO (1942) lamented after completion of a study of digestive systems and feeding habits of 150 species, that his results were not as "interesting" as he had expected them to be. Confusion in attempts to correlate ecology and morphology can arise from several factors: (1) Structure and ecology of a species progenitor is rarely known, and mainly must be speculated upon. (2) Rarely is sufficient information available concerning the ecology of the species throughout its entire geographical range, or entire life history, or even continuously over short periods. (3) The species we observe, mainly the successful survivors of different selection pressures, may be using structures to serve more than one function. The case of pharyngeal teeth which function both in sound production, and in feeding is a relevant example. (4) A majority of fishes will feed opportunistically, making it difficult to generalize from incidental observations.

Evolutionists often apply research results based on minimal probabilities, the specialist simply integrating data in his own mind-computer. Resource exploitation studies reduce the observations of organisms and their feeding habits to fit stylized curves of normal distribution. The excitement of in situ observations in the sea is finally forcing scientists of these divergent specializations to draw conclusions together. Hopefully, a hybrid vigor will result from this promising disciplinary cross.

Striking cases of fish communities which have evolved parallel to the coral reef fish community are found in the Great Lakes of Africa (FRYER \& ILEs 1972). FRYER (1959) started a small controversy when he proposed that species which continued plankton feeding as adults might be regarded as examples of "ecological neoteny". Since juveniles of many species forage on zooplankton, to retain the habit of foraging on this resource, together with shoaling, was to retain young/juvenile characteristics. MYers (1960) did not lend credence to this proposal, and subsequent authors have ignored some of the basic truths in this concept. During the ontogeny of species which forage benthically, the morphological changes involve greater ossification of the jaws and "pharyngeal mills" in cichlids, centrarchids, pomadasyids, sparids, and numerous other perciform families. Likewise, distinct juvenile color patterns are most often found in territorial benthic foraging forms. Among the water-column foragers, however, the basic adaptive modifications for feeding remain virtually unchanged during ontogeny. Consequently, the morphological hard parts, and associated musculature which ultimately represents the taxonomic distinction among various benthic forms, simply does not differentiate comparably in adults of water-column foraging species.

Color patterns of young and juvenile water-column foragers rarely are markedly distinct from adult color and pigment patterns. FRICKE (1972 and personal communication) demonstrates that the juvenile pattern of strongly territorial forms suppresses aggressive drives by adult fishes against weaker juveniles of the same species. It is, therefore, considered significant that the contrasting adaptations for water-column foraging does not include a "young or juvenile" color pattern, probably a corollary to the defensive nature of schooling. The question of whether to call this "ecological 
neotony" or not is secondary to the clear set of factors which lead to evolution of a water-column forager.

The systematic result of this "arrested" or early stabilized development is that all the best specialized water-column foragers have traditionally been placed in taxonomically separated genera, and in many cases split off into separate families. Only because Serranidae is a well accepted "catch basket" for diverse, yet basic perciform fishes, has Schultzea beta not been placed in a separate family distinguished by its toothless condition. As the systematically attuned reader has undoubtedly noticed, we have considered Emmelichthyops and Inermia as forms of Lutjanidae, the snapper family, rather than members of a separate family composed of only plankton feeders. Using this approach, one has little problem in placing the Indo-Pacific forms Caesio and Paracaesio with lutjanids; Caesioperca is then a serranid (in agreement with literature), representing a Pacific counterpart of Paranthias of the Atlantic Ocean.

\section{SUMMARY}

1. Radiation of fishes representing many families in the tropical coral reef has repeatedly produced convergence in the specialization for "water-column foragers".

2. This life mode is depicted by a recognizable set of morphological and behavioral characteristics. Exploitation of this niche has parallel examples in fresh water, and non-tropical habitats.

3. The distinguishing traits of this specialization, and the systematic, ecological and evolutionary features are described and discussed.

Acknowledgements. This study has drawn information from multiple sources involving efforts of many researchers. Many of the field observations from South Florida were made with the support of National Science Foundation Grant GB-1450, Dr. C. R. Robins, dhief investigator. During 1961-1966 the authors were provided with generous hospitality of Captain and Mrs. W. E. Starck, Lower Matecumbe Key, Florida. Night dives at Alligator Reef would probably never have been accomplished without the joint efforts and accompaniment of Dr. W. A. and J. D. Starck. Dr. A. EmERY provided much useful discussion and constructive criticism. The National Geographic Society is gratefully acknowledged for valuable photographic support during these dives, and granting subsequent permission to publish copyrighted illustrations. Conversations with Dr. H. Fricke proved most valuable during final preparation of the manuscript.

\section{LITERATURE CITED}

Alldredge, A. L., 1972. Abandoned larvacean houses: a unique food source in the pelagic environment. Science, N. Y. 177, 885-887.

Allen, G. R., 1972. Anemone fishes. T. F. H. Publs, Hongkong, 288 pp.

BöHLKE, J. E. \& Chaplin, C. C. G., 1968. Fishes of the Bahamas and adjacent tropical waters. Livingston, Place, Pa., $771 \mathrm{pp}$.

Brock, V. E, \& ChambertanN, T. C., 1968. A geological and ecological reconnaissance off Western Oahu, Hawaii, principally by means of the research submarine "Asherah". Pacif. Sci. 22, 373-394. 
ClArke, T. A., 1970. Territorial behavior and population dynamics of a pomacentrid fish, the garibaldi, Hypsypops rubicunda. Ecol. Monogr. 40, 180-212.

Conen, D. M. \& Davis, W. P., 1969. Vertical orientation in a new gobioid fish from New Britain. Pacif. Sci. 23, 317-324.

Collette, B. B. \& Talbot, R. H., 1972. Activity patterns of coral reef fishes with emphasis on nocturnal-diurnal change-over. Los Ang. Mus. Sci. Bull. 14, 98-124.

DAvis, W. P., 1967. Ecological interactions, comparative biology and evolutionary trends of thirteen pomadasyid fishes at Alligator Reef, Florida Keys. Diss. Univ. Miami, Coral Gables, 128 pp.

- \& CoHen, D. M., 1968. A gobiid fish and a palaemonid shrimp living on an antipatharian sea whip in the tropical Pacific. Bull. mar. Sci. 18, 749-761.

EIBL-EIBELSFELDT, I., 1962. Freiwasserbeobachtungen zur Deutung des Schwarmverhaltens verschiedener Fische, Z, Tierpsychol. 19, 165-182.

Emery, A. R., 1968. Preliminary observations on coral reef plankton. Limnol. Oceanogr. 13, 293-303.

FrdDeRn, H. A., 1963. Color changes during growth of Bodianus puchellus and B. rufus (Pisces: Labridae). Bull. mar. Sci. Gulf. Caribb. 13, 224-241.

- 1965. The spawning, growth, and general behavior of the bluehead wrasse, Thalassoma bifasciatum (Pisces: Labridae). Bull. mar. Sci. 15, 896-941.

Fisuelson, L., 1964. Observations of the biology and behaviour of Red Sea coral fishes. Bull. Sea Fish Res. Stn. Israel 37, 11-26.

Fricke, H. W., 1970. Olkologische und verhaltensbiologische Beobachtungen an den Rohrenaalen Gorgasie sillneri und Taenioconger bassi (Pisces, Apodes, Heterocongridae). Z. Tierpsychol. 27, 1076-1099.

- 1972. Korallenmeer. Belser, Berlin, 224 pp.

Fryer, G., 1959. Some aspects of evolution in Lake Nyasa. Evolution, Lancaster, Pa. 13, $440-451$.

Fryer, G. \& Iles, T. D., 1972. The cichlid fishes of the Great Lakes of Africa, their biology and evolution. Oliver \& Boyd, Edinburgh, $641 \mathrm{pp}$.

Hratt, R. W. \& Strasburg, D. W., 1960. Ecological relationships of the fish fauna on coral reefs on the Marshall Islands. Ecol. Monogr. 30, 65-127.

I-tosson, E. S., 1965. Diurnal-nocturnal activity of some inshore fishes in the Gulf of California. Copeia 1965, 291-302.

- 1968. Predatory behavior of some shore fishes in the Gulf of California. Res. Rep. U. S. Fish. Wildl. Serv. 73, 1-92.

- 1973. Diel feeding migrations of tropical reef fishes. Helgoländer wiss. Meeresunters. 24, $361-370$.

Lack, D., 1971. Ecological isolation in birds. Blackwell, Oxford, 404 pp.

Longley, W. H. \& Hildebrand, S. F., 1941. Systematic catalogue of the fishes of Tortugas, Florida, with observations on color, habits, and local distribution. Pap. Tortugas Lab. 34, 331.

MacArthur, R. H. \& Levins R., 1964. Competiton, habitat selection and character displacement in a patchy environment. Proc. natn. Acad. Sci. U.S.A. 51, 1207-1210.

Manteifel, B. P. \& Radakov, D. V., 1961. The adaptive significance of schooling behaviour in fishes. Russ. Rev. Biol. 50, 338-345.

Myers, G. S., 1960. Fish evolution in Lake Nyasa. Evolution, Lancaster, Pa. 14, 394-396.

Randalt, J. E., 1963. An analysis of the fish populations of artificial and natural reefs in the Virgin Islands. Caribb. J. Sci. 3, 31-47.

- 1965. Grazing effect on sea grasses by herbivorous fishes in the West Indies. Ecology 46, 255-260.

- 1967. Food habits of reef fishes of the West Indies. Stud. trop. Oceanogr. 5, 665-847.

- 1968a. Ioglossus helenae, a new gobiid fish from the West Indies. Ichthyologica 39, 107-116.

- 1968b. Caribbean Reef Fishes. T. F. H. Publ., Hongkong, 318 pp.

Robins, C. R. \& StaRck, W. A., II, 1961. Materials for a revision of Serranus and related fish genera. Proc. Acad. nat. Sci. Philad. 113, 259-314. 
Root, R. B., 1967. The niche exploitation pattern of the blue-gray Gnatcatcher. Ecol. Monog. $37,317-350$.

Sмrth, C. L., 1971. A revision of the American groupers: Epinepbelus and allied genera. Bull. Am Mus. nat. Hist. 146 (2), 241.

- \& TrLer, J. C., 1972. Space resource sharing in a coral reef fish community. Los Ang. County Mus. Sci. Bull. 14, 125-170.

StARCK, W. A., 1966. Marvels of a coral realm. Nat. Geo. 130, 710-738.

- 1968. A list of fishes of Alligator Reef, Florida with comments on the nature of the Florida Reef fauna. Undersea Biol. 1, 1-40.

- \& Davrs, W. P., 1966. Night habits of fishes of Aligator Reef, Florida. Ichthyologica 38, 313-356.

- \& Schroeder, R. E., 1971. Investigations of the gray snapper, Lutjanus grisens. Stud. trop. Oceanogr. 10, 224.

Strasburg, D. W., 1966. Observations on the ecology of four apongonid fishes. Pacif. Sci. 20, $338-341$.

SUYEHIRO, Y., 1942. A study of the digestive system and feeding habits of fish. Jap. J. Zool. 10, 1-303.

TAlbo', F. H, 1965. A description of the coral structure of Tutia Reef (Tanganyika Territory, East Africa), and its fish fauna. Proc. zool. Soc. Lond. 145, 43-470.

First author's address: Dr. W. Davis

Mediterranean Marine Sorting Center

Khereddine

Tunisia 